\title{
Occurrence of entomopathogenic nematodes in Polish soils
}

\author{
Ocorrência de nematoides entomopatogênicos em solos da Polônia
}

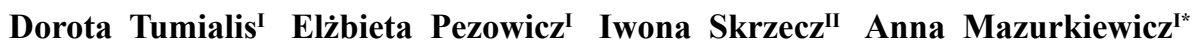
Justyna Maszewska I Joanna Jarmuł Pietraszczyk ${ }^{I}$ Kornelia Kucharska ${ }^{I}$
\end{abstract}

\section{- NOTE -}

ABSTRACT

Entomopathogenic nematodes (Steinernematidae and Heterorhabditidae) were studied in Polish soils according to the: season, habitat and altitude. In total, 167 soil samples were taken from 111 localities in Poland along north-south transect. Entomopathogenic nematodes were isolated from 53 soil samples (31.7\%). Nematodes species were identified genetically from 16 samples, and in all other 37 samples nematodes were determined to the genus level. Three species of the genus Steinernema (Steinernema kraussei, S. feltiae, S. carpocapsae) and one of the genus Heterorhabditis (Heterorhabditis megidis) were recorded. Steinernema feltiae was the most common species. There was not a significant association between the occurrence of nematodes and season or altitude. The type of habitat significantly $(P<0.05)$ affected the occurrence of nematodes. Nematodes were most frequent in samples collected from coniferous forests (20 findings).

Key words: distribution, Steinernema, Heterorhabditis, Poland, season, habitat.

\section{RESUMO}

Osnematoides entomopatogênicos (Steinernematidae e Heterorhabditidae) foram estudados em solo polonês de acordo com estação, habitat e altitude. Foram coletadas um total de 167 amostras de solo em 111 localidades diferentes ao longo da trajeto Norte-Sul da Polonia. Os nematoides entomopatogênicos foram extraidos em 53 das amostras de solo $(31,7 \%)$. As espécies de nematoides foram geneticamente identificadas a partir de 16 amostras, as outras 37 amostras foram usadas para determinar o gênero. Três espécies do gênero Steinernema (Steinernema kraussei, S. feltiae, S. carpocapsae) e uma espécie do gênero Heterorhabditis (Heterorhabditis megidis) foram identificadas. A espécie mais comum foi a $\boldsymbol{S}$. feltiae. Não foi encontrada uma relação significativa entre a presença de nematoides com a estação do ano e a altitude. $O$ tipo de habitat afetou significativamente
$(P<0,05)$ a ocorrência de nematoides. Os nematoides foram encontrados mais frequentemente em amostras recolhidas em florestas de coniferas (20 no total).

Palavras-chave: distribuição, Steinernema, Heterorhabditis, Polônia, estação, habitat.

Entomopathogenic nematodes (EPNs) are cosmopolitan organisms living on all continents except Antarctica. One of the most common species in the world is Steinernema feltiae (Filipjev), which prefers temperate zones. Less frequent but also of global range is $\boldsymbol{S}$. carpocapsae (Weiser). Steinernema feltiae and $\boldsymbol{S}$. affine (Bovien) are most often isolated species from among Steinernematidae family in Europe. Other European species include S. carpocapsae (isolated in Portugal, Slovakia, Germany, Italy, Spain and Switzerland), S. glaseri (Peters) (Portugal and Spain), S. kraussei (Steiner) (Belgium, Czech Republic, Slovakia, Germany, Switzerland and Great Britain), S. intermedium (Poinar) (Czech Republic, Slovakia, Germany and Switzerland), S. bicornutum Tallosi, Peters \& Ehlers (Slovakia, Czech Republic, Germany and Switzed), S. arenarium (Artyukhovsky) (southern Italy). From Heterorhabditidae family, Heterorhabditis bacteriophora (Poinar) and $\boldsymbol{H}$. megidis Poinar, Jackson \& Klein belong to the species of world range and occur frequently (HOMINICK, 2002). However, nematodes of the family Heterorhabditidae are rarely

\footnotetext{
'Department of Animal Environment Biology, Faculty of Animals Sciences, Warsaw University of Life Sciences (SGGW), Warsaw, Poland. E-mail: anna_mazurkiewicz@sggw.pl. "Corresponding author.

"Department of Forest Protection, Forest Research Institute, Sękocin Stary, Poland. 
isolated in Europe (HOMINICK, 2002) and some have a limited range. Research on the occurrence of EPNs in Poland has been conducted since the 1990s. So far, the presence of the following species: $\boldsymbol{S}$. feltiae, $\boldsymbol{S}$. affine, $S$. bicornutum, $S$. carpocapsae, $S$. arenarium, S. kraussei, $\boldsymbol{H}$. megidis and $\boldsymbol{H}$. bacteriophora (BEDNAREK, 1990; DZIĘGIELEWSKA \& KIEPAS-KOKOT, 2004; DZIĘGIELEWSKA, 2012; TUMIALIS et al., 2014) has been established. Missing genetically verified data from Poland and the dispersion of such information in only local journals justifies the need for this publication.

Soil samples were collected in spring (April to June), summer (July to September) and autumn (September to November) in 2010 and 2011. In total, 167 soil samples were taken from 111 localities in Poland along north-south transect. Sites of sample collection were selected to reflect the spectrum of diversity of habitats and climate in Poland. Soil samples were taken from various places like forests, fields, meadows and barren lands. From each site, 5 soil samples were taken with the Egner probe to a depth of $15-25 \mathrm{~cm}$ of a combined mass of $1 \mathrm{~kg}$ soil per site. In the laboratory, EPNs were isolated with the trap method using live bait (larvae of Galleria mellonella L., Lepidoptera: Pyralidae) (BEDDING \& AKHURST, 1975). White's traps (WHITE, 1927) were used to collect infective juveniles (IJs) of nematodes. Traps were placed in an incubator at $25^{\circ} \mathrm{C}$. After two weeks, IJs were obtained from dead insects, pipetted to bottles for tissue culture and placed in water. Bottles were preserved in a refrigerator at $4^{\circ} \mathrm{C}$. Nematodes were identified using morphological criteria (ADAMS \& NGUYEN, 2002). Infective juveniles from each sample were used for genetic identification. The identification of species was based on conserved regions $18 \mathrm{~S}$ and $26 \mathrm{~S}$. DNA of each nematode species was extracted from few (20-30) individuals. In the PCR reactions, one set of primers was used: $18 \mathrm{~S}$ (5'-TTGATTACGTCCCTGCCCTTT-3') and 26S (5'-TTTCACTCGCCGTTACTAAGG-3') as described by VRAIN et al. (1992), corresponding to nucleotide position 2503-2523 and 3774-3794, respectively, of the sequence of rDNA tandem unit from Caenorhabditis elegans (GenBank accession number X03680). PCR products were purified by ethanol precipitation and used for direct sequencing with the BigDyeTerminator Cycle Sequencing Ready Reaction Kit v. 3.1. (Life Technologies). Complete sequences of the ITS1-5.8S-ITS2 region of the rDNA cistron (977bp) were obtained for 16 samples of nematodes. Sequencing quality and counting assembly were checked using Pregap4 and Gap4 programmes (STADEN, 1996). All alignments were verified manually. The obtained results were statistically processed using STATISTICA 8.0 and PQStat 1.4. Pearson's chi square test was used to verify the relationship between nematode occurrence, season, habitat type and altitude. For small and unequal groups the Fisher's exact test was used.

Entomopathogenic nematodes were isolated from 53 out of 167 analysed soil samples (31.7\%). Most of them were nematodes from the genus Steinernema, which were isolated from 48 (90.6\%) samples. Nematodes of the genus Heterorhabditis were isolated from 4 (7.5\%) samples, and one sample $(1.9 \%)$ contained representatives of both families. Nematode species were identified genetically from 16 samples. The presence of $\boldsymbol{S}$. feltiae was recorded in 11 samples, $\boldsymbol{S}$. kraussei was found in 4 samples, S. carpocapsae in one and two samples contained $\boldsymbol{H}$. megidis. Three species $-S$. feltiae, S. carpocapsae and $\boldsymbol{H}$. megidis - were reported together in one sample. In the remaining 37 samples, nematodes were determined to the genus level. From among 22 samples collected in spring, 21 contained nematodes of the genus Steinernema with $\boldsymbol{S}$. feltiae found in 7 samples and $\boldsymbol{S}$. kraussei in one. In summer, nematodes of the genus Steinernema were isolated from 9 samples (S. feltiae in 1 sample and $\boldsymbol{S}$. carpocapsae in 1 sample) and those from the genus Heterorhabditis were reported in two samples (H. megidis in one sample). Out of 21 samples taken in autumn, entomopathogenic nematodes from the Steinernematidae family were isolated from 19 samples (S. feltiae in three samples, S. kraussei in one sample) and Heterorhabditidae nematodes from two samples (H. megidis in one sample). The performed studies did not show statistically significant seasonal differences in the presence of nematodes $(P>0.05)$. Entomopathogenic nematodes were isolated from all six types of habitats (Figure 1). The type of habitat significantly $(P<0.05)$ affected the occurrence of nematodes. Nematodes were most frequent (20 findings) in samples collected from coniferous forests (moist mixed coniferous forest on clayey-sandy soil and fresh coniferous forest on sandy soil), followed by those in fields (16 findings) and the least frequent in meadows (two findings). In total, 31 samples with nematodes were reported in forest habitats. Out of this, four contained $\boldsymbol{S}$. feltiae and 4 - S. kraussei. From meadows and barren lands, nematodes were isolated in a total of six samples; one sample showed the presence of $\boldsymbol{S}$. feltiae. In fields, nematodes of the family Steinernematidae were found in 12 samples - six of them contained 


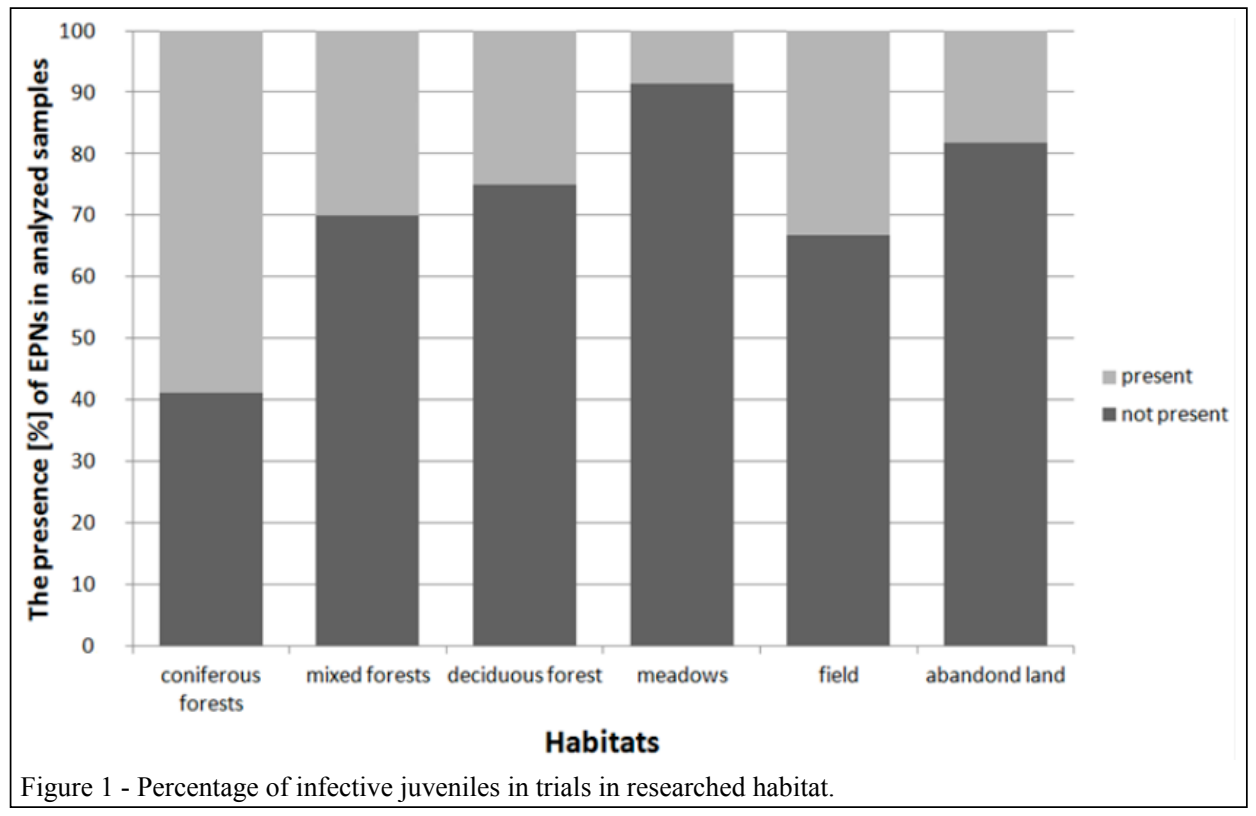

S. feltiae and one S. carpocapsae. Nematodes of the family Heterorhabditidae were noted only in four samples from fields; two of them contained H. megidis. Steinernema feltiae appeared as the dominating species (11 samples $=20.4 \%$ ) among all the isolated EPNs. It was most often isolated in spring ( 7 samples) from the fields. Steinernema kraussei constituted 7.5\% (4 samples) of all isolated species. In three out of four samples, S. kraussei was isolated from forests in spring and in one forest sample collected in autumn. Heterorhabditis megidis constituted $3.8 \%$ ( 2 samples) of all isolated species. In both cases, its presence was recorded in field samples; once in summer and once in autumn. The presence of $\boldsymbol{S}$. carpocapse was reported in only one sample $(1.9 \%)$ collected in summer from the field. No statistically significant effect $(P>0.05)$ of the altitude on the occurrence of EPNs was reported.

Summarizing, the following species of EPNs has been recorded in Poland: $\boldsymbol{S}$. feltiae, $\boldsymbol{S}$. affine, $\boldsymbol{S}$. bicornutum, S. carpocapsae, S. arenarium, S. kraussei, $\boldsymbol{H}$. megidis and $\boldsymbol{H}$. bacteriophora (DZIECGIELEWSKA \& KIEPAS-KOKOT, 2004; DZIĘGIELEWSKA, 2012; TUMIALIS et al., 2014). In this research from among 167 studied samples, nematodes were isolated from 53 samples (31.7\%). This result is similar to those obtained by DZIĘGIELEWSKA \& KIEPAS-KOKOT (2004) who isolated EPNs in 38 out of 97 samples (39\%) and by DZIEGIELEWSKA (2012) who analysed 156 samples and found EPNs in 43 of them (27.6\%). The nematodes from Steinernematidae, which constituted $92.5 \%$ of the records, were more frequently found in the presented study. Heterorhabditidae family was represented by only one species (H. megidis) found in two samples $(3.8 \%)$, which confirmed rarity of Heterorhabditidae nematodes in Europe (HOMINICK, 2002). Similar proportions were reported in studies by MRÁČEK (2005), DZIĘGIELEWSKA (2012) and STURHAN \& LIŠKOVÁ (1999). In this study, three species of the genus Steinernema and one species of Heterorhabditis were reported. In the present study, the dominating species $\boldsymbol{S}$. feltiae was reported in 11 samples (20.6\%). The observations made by BEDNAREK (1990) in agrocenosis in different regions of Poland showed the presence of $\boldsymbol{S}$. feltiae in $75.5 \%$ of samples with EPNs. DZIĘGIELEWSKA \& KIEPAS-KOKOT (2004) found $63 \%$ share of $\boldsymbol{S}$. feltiae in the assemblages of entomopathogenic nematodes dwelling in industrial areas, while in the studies carried out in orchards, its share was smaller $(27 \%)$, but the species was still dominating (DZIĘGIELEWSKA, 2012). In performed studies, $\boldsymbol{S}$. kraussei was reported in four samples (7.5\%), similarly to Slovakia (STURHAN \& LIŠKOVÁ, 1999). Nematodes were isolated in all seasons but no significant seasonal differences were found in the presence of nematodes. Similarly MRÁČEK (2005) and GARCIA DEL PINO (1996) did not find the relationship between the occurrence of EPNs and seasons. MRÁČEK (2005) collected the samples during the whole year, whereas Garcia Del Pino (1996) isolated nematodes in spring and autumn. In contrast, the season affects the number of individuals. MRÁČEK (1982) stated that there are two peaks of nematode abundance: in July and November. This author assumed that the high abundance in July 
resulted in the occurrence of favourable ecological conditions for nematodes. In contrast, the high abundance in autumn is associated with an increase of the number of soil hosts. The only species present in all seasons was $\boldsymbol{S}$. feltiae. In studies by MRÁČEK (2005) two species - S. feltiae and $\boldsymbol{S}$. kraussei - were isolated the year round. Most nematodes were found in samples isolated from coniferous forest soils. The same results were obtained in Slovakia, Germany and Czech Republic (STURHAN \& LIŠKOVÁ, 1999; MRÁČEK et al., 2005). When analysing the list of species and their distribution in neighbouring countries, one may expect more species than determined so far in Poland.

\section{ACKNOWLEDGMENTS}

The study was carried out in the framework of the Project N N309 4228838 financed by the Ministry of Science and Higher Education, Poland.

\section{REFERENCES}

ADAMS, B.J.; NGUYEN, K.B. Taxonomy and systematics. In: GAUGLER, R. (Ed.). Entomopathogenic nematology. Wallingford, UK: CABI Publishing, 2002. p.1-33.

BEDDING, R.A. \& AKHURST, R.J. A simple technique for the detection of insect parasitic rhabditid nematodes in soil Nematologica, v.21, p.109-110, 1975. Avallable From: <http:// dx.doi.org/10.1163/187529275x00419>. Accessed: Jul. 17, 2015. doi: 10.1163/187529275X00419.

BEDNAREK, A. Ekologiczne uwarunkowania aktywności biologicznej nicieni entomofilnych w środowisku glebowym agrocenoz. 1990. 108f. Rozprawy Naukowe i Monografie. Wydawnictwo SGGW-AR.

DZIĘGIELEWSKA, M.; KIEPAS-KOKOT, A Występowanie nicieni owadobójczych w glebach na terenach przemysłowych. Zeszyty Problemowe Postępów Nauk Rolniczych, v.501, p.95-101, 2004.

DZIĘGIELEWSKA, M. Występowanie nicieni owadobójczych z rodziny Steinernematidae i Heterorhabditidae w sadach chronionych i niechronionych chemicznie. Progress in Plant Protection, v.52, n.2, p.415-420, 2012. Available from: $<$ http:// www.progress.plantprotection.pl/download.php?ma_id $=1056>$. Accessed: Jul. 17, 2015.
GARCIA DEL PINO, F.; PALOMO, A. Natural occurrence of entomopathogenic nematodes (Rhabditida: Steinernematidae and Heterorhabditidae) in Spanish soils. Journal of Invertebrate Pathology, v.68, p.84-90, 1996. Available from: <http://www. sciencedirect.com/science/article/pii/S0022201196900622>. Accessed: Jul. 17, 2015. doi: 10.1006/jipa.1996.0062.

HOMINICK, W.M. Biogeography. In: GAUGLER, R. (Ed.). Entomopathogenic nematology. Wallingford, UK: CABI Publishing, 2002. p.115-143.

MRÁČEK, Z. Horizontal distribution in soil, and seasonal dynamics of the nematode Steinernema kraussei, a parasite of Cephalcia abietis. Zeitschrift für Angewandte Entomologie, v.94, p.110-112, 1982. Available from: <http://onlinelibrary.wiley. com/doi/10.1111/j.1439-0418.1982.tb02553.x/pdf>. Accessed: . Jul. 17, 2015. doi: 10.1111/j.1439-0418.1982.tb02553.x.

MRÁČEK, Z. et al. Habitat preference for entomopathogenic nematodes, their insect hosts and new faunistic records for the Czech Republic. Biological Control, v.34, p.27-37, 2005. Available from: <http://www.sciencedirect.com/science/article/ pii/S104996440500085X>. Accessed: Jul. 17, $2015 . \quad$ doi: 10.1016/j.biocontrol.2005.03.023.

STADEN, R. The staden sequence analysis package. Molecular Biotechnology, v.5, p.233-241, 1996. Available from: <http:/ link.springer.com/article/10.1007\%2FBF02900361>. Accessed: Jul. 17, 2015. doi: 10.1007/BF02900361.

Sturhan, D.; Liskova, M. Occurrence and distribution of entomopathogenic nematodes in the Slovak Republic. Nematology, v.1,n.3, p.273-277, 1999. Available from: <http://booksandjournals. brillonline.com/content/journals/10.1163/156854199508261>. Accessed: Jul. 17, 2015. doi: 10.1163/156854199508261.

TUMIALIS, D. et al. Steinernema kraussei (Steiner, 1923) (Rhabditida: Steinernematidae) - the first record from Poland. Helminthologia, v.51, n.2, p.162-166, 2014. Available from: $<$ http://link.springer.com/article/10.2478\%2 Fs11687-014-0224-9>. Accessed: Dec. 15, 2015 . doi: 10.2478/ s11687-014-0224-9.

VRAIN, T.C. Intraspecific rDNA restriction fragment length polymorphisms in the Xiphinema americanum group. Fundamental and Applied Nematology, v.15, p.563-574, 1992. Available from: <http://horizon.documentation.ird.fr/exl-doc/ pleins textes/fan/40261.pdf>. Accessed: Jul. 17, 2015.

WHITE, G.F. A method for obtaining infective nematode larvae from cultures. Science, v.66, p.302-303, 1927. Available from: $<$ http://science.sciencemag.org/content/66/1709/302.2.long $>$.. Accessed: Jul. 17, 2015. doi: 10.1126/science.66.1709.302. 